\title{
Factors of chemoresistant pulmonary tuberculosis progression in patients receiving palliative treatment
}

\author{
0. M. Raznatovska, G. V. Khudiakov
}

Zaporizhzhia State Medical University, Ukraine

Key words: drug-resistant tuberculosis, palliative care, quality of life, tumor necrosis factor, body mass index.

\section{Zaporozhye} medical journal 2018; 20 (3), 388-391 DOl: 10.14739/2310-1210 2018.3.130829

\section{E-mail:}

raxnatovskaya@ gmail.com
Objective - to define factors of chemoresistant pulmonary tuberculosis (CRPTB) progression in patients receiving palliative treatment by means of their QL, TNF- $\alpha$ levels and body mass index complex assessment.

Materials and methods. 81 CRPTB patients were examined and divided into two groups: the main group consisted of 52 patients receiving palliative treatment and the control group consisted of 29 patients receiving antimycobacterial therapy by category 4 according to drug resistance. The MOS SF-36 questionnaire was used to evaluate the quality of life. Studies of serum TNF- $a$ level were determined by enzyme-linked immunosorbent assay using immunoenzymometric reader Sirio $S$ and a set "Bender MedSystems $\mathrm{GmbH}$ " (Austria), (pg/ml). Body mass index was calculated with the help of calculator New BMI (New Body Mass Index), $\left(\mathrm{kg} / \mathrm{m}^{2}\right)$. Results of this study were processed using the modern methods of analysis with the help of a personal computer and the statistical package of the licensed software program Statistica ${ }^{\circledR}$ for Windows 6.0 (StatSoft Inc., № AXXR712 D833214FAN5).

Results. CRPTB patients receiving palliative treatment have simultaneously a high activity of inflammatory specific process, predominant body mass deficit and low quality of life (both its physical and mental component). And along with this in patients receiving CRPTB treatment, activity of specific inflammatory process is 2.2 times lower, normal level of body weight predominate and quality of life is satisfactory (with satisfactory levels of both its components). Assessment of correlation relationships gave an opportunity to find out that in CRPTB patients, receiving palliative treatment, absence of the specific process antimycobacterial therapy leads to an increase in blood serum TNFa which in its turn promotes development of body mass deficit and as a consequence quality of life is decreased through decrease of all its components. In patients receiving etiotropic treatment activity of specific inflammatory process promotes decrease of body mass and quality of life but these changes are not so expressed as in case with patients receiving palliative treatment.

Conclusions. Factors of CRPTB progression in patients receiving palliative treatment include increase of TNFa level in the blood serum ( $\geq 180 \mathrm{pg} / \mathrm{ml})$, deficit in body mass $\left(\leq 18.1 \mathrm{~kg} / \mathrm{m}^{2}\right)$, decrease in quality of life index ( $\leq 50$ relative units).
Киючові слова: хіміорезистентний туберкульоз мегень, паліативне мікування, якість життя, фактор некрозу пухмин, індекс маси тіка.

Запорізький медичний журнал. - 2018. T. 20, № 3(108), C. 388-391

\section{Фактори прогресування хіміорезистентного туберкульозу мегень у хворих, які перебувають на паліативному лікуванні}

\section{О. М. Разнатовська, Г. В. Худяков}

Мета роботи - визначення факторів прогресування хіміорезистентного туберкульозу (ХРТБ) легень у хворих, які перебувають на паліативному лікуванні, шляхом комплексного оцінювання якості життя, а також рівнів TNF- $\alpha$ та індексу маси тіла.

Матеріали та методи. Обстежили 81 хворого на ХРТБ легень. Пацієнтів поділили на 2 групи: основна - 52 особи, які перебувають на паліативному лікуванні, контрольна - 29 осіб, які отримують антимікобактеріальну терапію за категорією 4 відповідно до профрілю медикаментозної резистентності. Для оцінювання якості життя використовували опитувальник MOS SF-36. Дослідження рівня TNF-a в сироватці крові виконали методом твердофазного імуноферментного аналізу на приладі імуноферментний рідер Sirio S із застосуванням набору «Bender MedSystems GmbH» (Austria), (пкг/мл). Для розрахунку індексу маси тіла використовували калькулятор New BMI (New Body Mass Index), (кг/м²). Результати дослідження опрацювали сучасними методами аналізу на персональному комп'ютері з використанням статистичного пакета ліцензійної програми Statistica ${ }^{\circledR}$ for Windows 6.0 (StatSoft Inc., № AXXR712 D833214FAN5).

Результати. У хворих на ХРТБ легень, які перебувають на паліативному лікуванні, визначили високу активність запального специфічного процесу, переважання дефіциту маси тіла та низьку якість життя (як фізичного, так і психічного компонента). Коли у хворих, які отримували лікування хіміорезистентного туберкульозу легень, активність запального специфічного процесу у 2,2 раза нижча, переважає нормальний рівень маси тіла та задовільна якість життя із задовільними рівнями обох її компонентів. Оцінювання кореляційних зв'язків показало: у хворих на ХРТБ, які перебувають на паліативному лікуванні, відсутність антимікобактеріальної терапії специфічного процесу призводить до зростання рівня TNFa в сироватці крові, спричиняючи розвиток дефріциту маси тіла, а отже і зниження якості життя внаслідок зниження всіх його компонентів. У пацієнтів, які отримують етіотропну терапію, активність запального специфічного процесу зумовлює зниження маси тіла та якості життя, але ці зміни не настільки виражені, як у хворих, котрі знаходяться на паліативному лікуванні.

Висновки. Факторами прогресування ХРТБ легень у хворих, які перебувають на паліативному лікуванні, є зростання рівня TNFa в сироватці крові ( $\geq 180$ пкг/мл), дефріцит маси тіла ( $\leq 18,1$ кг/M²), зниження показника якості життя ( $\leq 50$ ум. од.).

\section{Факторы прогрессирования химиорезистентного туберкулеза легких у больных, которые находятся на памиативном лечении}

\section{Е. Н. Разнатовская, Г. В. Худяков}

Цель работы - определение факторов прогрессирования химиорезистентного туберкулеза (ХРТБ) легких у больных, которые находятся на паллиативном лечении, путем комплексной оценки качества жизни, уровня TNF-a и индекса массы тела. 
Материалы и методы. Обследовали 81 больного ХРТБ легких. Пациентов поделили на 2 группы: основная - 52 больных, находящихся на паллиативном лечении, контрольная - 29 пациентов, получающих антимикобактериальную терапию по категории 4 в соответствии с профилем медикаментозной резистентности. Для оценки качества жизни использовали опросник MOS SF-36. Исследование уровня TNF-a в сыворотке крови проводили методом твердофразного иммуноферментного анализа на приборе иммуноферментный ридер Sirio S c применением набора «Bender MedSystems GmbH» (Austria), (пг/мл). Для расчета индекса массы тела использовали калькулятор New BMI (New Body Mass Index), (кг/M²). Результаты исследования обработаны современными методами анализа на персональном компьютере с использованием статистического пакета лицензионной программы Statistica® for Windows 6.0 (StatSoft Inc., № AXXR712 D833214FAN5).

Результаты. У больных с ХРТБ легких, которые находятся на паллиативном лечении, определена высокая активность воспалительного специфического процесса, преобладание дефицита массы тела и низкое качество жизни (как физического, так и психического компонента). Когда у больных, получающих лечение химиорезистентного туберкулеза легких, активность воспалительного специфического процесса в 2,2 раза ниже, преобладает нормальный уровень массы тела и удовлетворительное качество жизни с удовлетворительными уровнями обоих ее компонентов. Оценка корреляционных связей позволила установить, что у больных с ХРТБ легких, которые находятся на паллиативном лечении, отсутствие антимикобактериальной терапии специфического процесса приводит к повышению уровня TNF $\alpha$ в сыворотке крови, что обусловливает развитие дефицита массы тела, как следствие, снижается качество жизни за счет снижения всех ее компонентов. У пациентов, получающих этиотропную терапию, активность воспалительного специфического процесса способствует снижению массы тела и качества жизни, однако эти изменения не настолько выражены, как у больных, находящихся на паллиативном лечении.

Выводы. Факторами прогрессирования ХРТБ легких у больных, находящихся на паллиативном лечении, является повышение уровня TNFa в сыворотке крови ( $\geq 180$ пг/мл), дефицит массы тела ( $\left.\leq 18,1 \mathrm{kr} / \mathrm{M}^{2}\right)$, снижение показателя качества жизни ( $\leq 50$ усл. ед.).

Along with the problem of chemoresistant pulmonary tuberculosis (CRPTB) treatment efficacy improvement, currently there is another urgent issue in the world, including Ukraine. And this issue is the tactics of disease management in CRTB patients receiving palliative treatment [8]. It is often that in case with long standing tuberculosis patients develop resistance to many antimycobacterial drugs (AMBD) that complicates tuberculosis course and could lead to impossibility of antimycobacterial therapy (AMBT) and transition to palliative treatment of tuberculosis.

The World Health Organization (WHO) recommended assessing status of patients receiving palliative treatment by means of quality of life questionnaires (QL) which are integral indicators of person's general wellbeing $[1,2]$.

According to literature data application of the Russian version of questionnaire Medical Outcomes Study-Short Form (MOS) SF-36, developed by J. E. Ware in 1992 [9] and translated by researchers of the Multinational Center of Quality of Life Research (MCQLR, Saint Petersburg) in 1998 [3], can be used not only for QL population-based researches of healthy persons but also for researches in case of various diseases, including tuberculosis [4-6,10,11].

Cachexia-related cardiac failure is one of causes of patients' death in case of CRPTB. This cardiac failure is a frequent catabolic syndrome in case of a chronic specific process. That is why it is essential to improve QL of CRPTB patients receiving palliative treatment. And this is of particular importance for patients with the end stage of disease when catabolic processes are progressive and significantly worsen their general condition.

Hong-Min F. A. N. et al. (2010) [12] have revealed a synergistic interaction between the genotype of Tumor Necrosis Factor (TNF)- $\alpha-308$ GG and Body Mass Index. In addition to that data an interaction between TNF-a-238 GG genotype and the risk of pulmonary tuberculosis development has been indicated by their researches: multiple correlation coefficients for TNF- $\alpha-238$ GG and TNF- $\alpha-308$ GA genotypes were 1,98 (95\% confidence interval $(\mathrm{Cl})$ 1.06-3.71) concerning the risk of pulmonary tuberculosis development. A Moges B. et al. (2012) [13] have revealed correlation between the prevalence of tuberculosis among prisoners in Ethiopia and body mass deficit (BMD).

After literature data analysis we defined that the urgent matter consists in a complex study of catabolic processes and QL of CRPTB patients receiving palliative treatment for the purpose of cachexia prevention.

\section{Objective}

To define factors of chemoresistant pulmonary tuberculosis progression in patients receiving palliative treatment by means of their QL, TNF- $\alpha$ levels and body mass index (BMI) complex assessment.

\section{Materials and methods}

81 CRPTB patients receiving treatment in the Municipal Institution "Zaporizhzhia Regional Hospital" and in specialized tuberculosis hospital of the State Institution "Sofia Correctional Facility No. 55" of the Ministry of Justice of Ukraine in Zaporizhzhia Region participated in the study. All patients (100\%) were males. Their average age was $40.1 \pm 12.1$ years. The patients were divided into two groups: the main group consisted of 52 patients receiving palliative treatment and the control group consisted of 29 patients receiving AMBT by category 4 according to drug resistance in compliance with Unified Clinical Protocol of Medical Care "Tuberculosis" (Order by the Ministry of Health Care of Ukraine No. 620 of September 04, 2014) [7]. Comparison groups were comparable by age and gender.

QL assessment was performed by means of questionnaire MOS SF-36 (MCQLR, Saint Petersburg, 1998) using. According to questionnaire MOS SF-36 8 scales were assessed: Physical Functioning (PF) - physical functions; Role-Physical (RP) - influence of physical condition on role playing; Bodily Pain (BP) - intensity of pain and its influence on ability to perform daily activities; General Health (GH) - general health condition; Vitality (VT) - vital capacity; Social Functioning (SF) - performing social functions; Role-Emotional (RE) - influence of emotional condition on
Киючевые слова: химиорезистентный туберкулез легких, паммиативное мечение, качество жизни, фактор некроза опухоли, индекс массы тела.

\section{Запорожский} медицинский журнал. - 2018. T. 20, № 3(108), C. 388-391 
Table 1. Indexes of TNFa, BMT and QL of CRPTB patients depending on the type of treatment, $M e\left[Q_{25} ; Q_{75}\right]$

\begin{tabular}{l|l|l|l} 
Index, units & Basic group $(\mathbf{n = 5 2 )}$ & Comparison group $(\mathbf{n = 2 9 )}$ & $\mathbf{p}$ \\
\hline TNFa, pg/ml & $180(80 ; 620)$ & $80(60 ; 120)$ & 0.007 \\
\hline BMI, $\mathrm{kg} / \mathrm{m}^{2}$ & $18.1(16.8 ; 21.2)$ & $20.8(18.9 ; 23.0)$ & 0.001 \\
\hline MCS, relative units & $52.1(37.5 ; 57.75)$ & $61.9(53.5 ; 69.8)$ & 0.0001 \\
\hline PCS, relative units & $49.6(39 ; 61)$ & $68.5(51.75 ; 77.25)$ & 0.0001 \\
\hline GI QL, relative units & $49.5(39.98 ; 60.05)$ & $66.9(51.3 ; 72.1)$ & 0.00002 \\
\hline
\end{tabular}

Table 2. Correlation relationships between indexes of TNFa, BMI and QL in CRPTB patients depending on the type of treatment

\begin{tabular}{|c|c|c|c|c|c|c|c|c|c|c|c|c|c|c|c|c|c|c|c|c|}
\hline \multirow[t]{3}{*}{ Index } & \multicolumn{10}{|c|}{ Basic group $(n=52)$} & \multicolumn{10}{|c|}{ Comparison group $(n=29$ ) } \\
\hline & \multicolumn{2}{|l|}{ TNFa } & \multicolumn{2}{|l|}{ BMI } & \multicolumn{2}{|l|}{ MCS } & \multicolumn{2}{|l|}{ PCS } & \multicolumn{2}{|c|}{ GI QL } & \multicolumn{2}{|l|}{ TNFa } & \multicolumn{2}{|l|}{ BMI } & \multicolumn{2}{|l|}{ MCS } & \multicolumn{2}{|l|}{ PCS } & \multicolumn{2}{|l|}{ GI QL } \\
\hline & $r$ & p & $r$ & $p$ & $r$ & $p$ & $r$ & $p$ & $r$ & $p$ & $r$ & $p$ & $r$ & $p$ & $\mathbf{r}$ & $p$ & $r$ & $p$ & $r$ & p \\
\hline TNFa & 1.00 & $>0.05$ & -0.76 & 0.001 & -0.51 & 0.001 & -0.49 & 0.001 & -0.55 & 0.001 & 1.00 & $>0.05$ & -0.49 & 0.01 & -0.47 & 0.01 & -0.40 & 0.03 & -0.46 & 0.01 \\
\hline BMI & -0.76 & 0.001 & 1.00 & $>0.05$ & 0.40 & 0.004 & 0.49 & 0.001 & 0.50 & 0.001 & -0.49 & 0.01 & 1.00 & $>0.05$ & 0.21 & 0.272 & 0.18 & 0.341 & 0.21 & 0.277 \\
\hline MCS & -0.51 & 0.001 & 0.40 & 0.004 & 1.00 & $>0.05$ & 0.63 & 0.001 & 0.89 & 0.001 & -0.47 & 0.01 & 0.21 & 0.272 & 1.00 & $>0.05$ & 0.77 & 0.001 & 0.94 & 0.001 \\
\hline PCS & -0.49 & 0.001 & 0.49 & 0.001 & 0.63 & 0.001 & 1.00 & $>0.05$ & 0.92 & 0.001 & -0.40 & 0.03 & 0.18 & 0.341 & 0.77 & 0.001 & 1.00 & $>0.05$ & 0.95 & 0.001 \\
\hline GI QL & -0.55 & 0.001 & 0.50 & 0.001 & 0.89 & 0.001 & 0.92 & 0.001 & 1.00 & $>0.05$ & -0.46 & 0.01 & 0.21 & 0.277 & 0.94 & 0.001 & 0.95 & 0.001 & 1.00 & $>0.05$ \\
\hline
\end{tabular}

role physical; Mental Health $(\mathrm{MH})$ - self-assessment of mental health condition.

Three generalized indexes were taken in this work for QL assessment: Physical Component Summary (PCS) which includes scales 1-4 (PF, RP, BP, GH), Mental Component Summary (MCS) which includes scales 5-8 (VT, $\mathrm{SF}, \mathrm{RE}, \mathrm{MH}$ ) and a Composite General Index of QL (GI $\mathrm{QL})$ which includes all scales (1-8) of the questionnaire (relative units).

The blood serum TNF-a level was studied by means of enzyme-linked immunosorbent assay using immunoenzymometric reader Sirio S and a set "Bender MedSystems GmbH" (Austria), (pg/ml).

Body Mass Index (BMI) was calculated with a help of calculator New BMI (New Body Mass Index), $\left(\mathrm{kg} / \mathrm{m}^{2}\right)$.

All patients signed patient's informed written consent for participation in this study.

Results of this study were processed using the modern methods of analysis with a help of a personal computer and the statistical package of the licensed software program Statistica $^{\circledR}$ for Windows 6.0 (StatSoft Inc., № AXXR712 D833214FAN5). Normality of quantitative indicators distribution was analyzed with a use of Shapiro-Wilks test. Descriptive statistics was presented in form of a median with interquartile range $-\mathrm{Me}\left[\mathrm{Q}_{25} ; \mathrm{Q}_{75}\right]$, as far as the matter was about the parameter which differed from the normal one. Significance of differences between the compared values was defined with a help of Mann-Whitney test. All tests were two-sided. Ap value $<0.05$ was considered statistically significant. Correlation analysis was performed with a use of Pearson correlation coefficient ( $r$ ).

\section{Results and discussion}

After assessment of indexes included in this study it was determined that CRPTB patients receiving palliative treatment had reliable changes of all parameters as compared to the group of patients receiving AMBT (Table 1). So, the blood serum TNFa level was 2.2 times higher (180 $(80 ; 620) \mathrm{pg} / \mathrm{ml}$ as compared to $80(60 ; 120) \mathrm{pg} / \mathrm{ml})$ and it indicated a high activity of inflammatory specific process in patients. Level of BMI was $14.9 \%$ lower and its average value was $18.1(16.8 ; 21.2) \mathrm{kg} / \mathrm{m}^{2}$. And this meant that body mass deficit (BMD) prevailed in patients with tuberculosis which is an unfavorable factor for cachexia development. GI QL was 1.3 times lower ((49.48 (39.98; 60.05) relative units) as compared to $66.9((51.3 ; 72.1)$ relative units)) by reducing MCS $(1.2$ times) $((52.1(37.5 ; 57.75)$ relative units) as compared to $61.9((53.5 ; 69.8)$ relative units $))$ as well as by reducing PCS $(1.3$ times) $((49.6(39 ; 61)$ relative units) as compared to $68.5((51.75 ; 77.25)$ relative units)).

Following the assessment of the correlation relationships between indexes of TNFa, BMI and QL in CRPTB patients depending on the type of treatment the resulting data were determined (Table 2). CRPTB patients receiving palliative treatment had significant correlation relationships between all these indexes. So, when the blood serum TNFa level increased there was a decrease in BMI $(r=-0.76$; $P=0.001)$ and $G I Q L(r=-0.51 ; P=0.001)$ through the significant reduction of its both general indexes MCS $(r=-0.51$; $P=0.001)$ and $P C S(r=-0.49 ; P=0.001)$. Decrease in $B M I$ had a direct correlation relationship with decrease in GI QL $(r=0.50 ; P=0.001)$ through reduction of its both general indexes MCS $(r=0.40 ; P=0.004)$ and PCS $(r=0.49$; $P=0.001)$. Decrease in $G I Q L$ was directly dependent on decline of MCS $(r=0.89 ; p=0.001)$, as well as on decline of PCS $(r=0.92 ; P=0.001)$.

In case with patients receiving treatment of CRPTB it was also that increase in blood serum TNFa level come against the background of $\mathrm{BMI}(r=-0.49 ; \mathrm{P}=0.01)$ and $\mathrm{GI} Q \mathrm{Q}(r=-0.46 ; P=0.01)$ reduction through significant lowering of both indexes MCS $(r=-0.47 ; P=0.01)$ and PCS ( $r=-0.40 ; P=0.03$ ). Increase of $G I Q L$ was directly dependent on increase in MCS $(r=0.94 ; P=0.001)$, as well as on decline of PCS $(r=0.95 ; P=0.001)$. Correlation relationships between $\mathrm{BMI}$ and $\mathrm{QL}$ indexes were not revealed.

\section{Conclusions}

1. CRPTB patients receiving palliative treatment have simultaneously a high activity of inflammatory specific process, predominant body mass deficit and low quality of life (its physical as well as mental component). And at 
the same time in patients receiving treatment of CRPTB activity of inflammatory specific process is 2.2 times lower, normal body mass level is dominant and quality of life is satisfactory (with satisfactory levels of its both components).

2. Assessment of correlation relationships provided an opportunity to find out that in CRPTB patients receiving palliative treatment absence of AMBT specific process leads to an increase in blood serum TNFa level which in its turn promotes development of body mass deficit and as a consequence quality of life is decreased (through decrease of its all components). In patients receiving conventional (etiotropic) treatment activity of inflammatory specific process promotes decrease in body mass and quality of life but these changes are not as expressed as in case with patients receiving palliative treatment.

3. Factors of CRPTB progression in patients receiving palliative treatment include increase in blood serum TNFa level ( $\geq 180 \mathrm{pg} / \mathrm{ml})$, body mass deficit $\left(\leq 18.1 \mathrm{~kg} / \mathrm{m}^{2}\right)$, decrease in quality of life index ( $\leq 50$ relative units).

Prospects of further researches. To develop the disease management algorithm for CRPTB patients receiving palliative treatment (taking into account the obtained data) that would promote their quality of life improvement.

Фінансування: АосліАження виконане в рамках НАР Запорізького державного медичного університету "Аослідження патогенетичних механізмів прогресування специфічного процесу, встановлення критеріїв неефективного лікування та розробка своєчасної їх корекції у хворих на туберкульоз мегень" № Аержреєстрації 0116 U005830 (2017-2021)

Conflicts of Interest: authors have no conflict of interest to declare. Конфиікт інтересів: віАсутній.

Information about authors:

Raznatovska O. M., MD, PhD, DSci, Associate Professor, Professor, Department of Phthisiology and Pulmonology, Zaporizhzhia State Medical University, Ukraine.

Khudiakov G. V., MD, Postgraduate Student, Department of Phthisiology and Pulmonology, Zaporizhzhia State Medical University, Ukraine.

Відомості про авторів:

Разнатовська О. М., А-р меА. наук, Аоцент, професор каф. фтизіатрії і пульмонології, Запорізький державний медичний університет, Україна.

Худяков Г. В., аспірант каф. фтизіатрії і пульмонології,

Запорізький державний медичний університет, Україна.

\section{Сведения об авторах:}

Разнатовська Е. Н., А-р меА. наук, Аоцент, профессор каф. фтизиатрии и пульмонологии, Запорожский государственный медицинский университет, Украина. ХуАяков Г. В., аспирант каф. фтизиатрии и пульмонологии, Запорожский государственный меАицинский университет, Украина.

Надійшла Ао редакції / Received: 09.11.2017

Після Аоопрацювання / Revised: 23.11.2017

Прийнято Ао Аруку / Accepted: 07.12.2017

\section{References}

[1] YeAPD. (2013). Prazka khartiia «Otrymannia paliatyvnoi dopomohy - pravo liudyny». [Prague Charter "Getting palliative care - a human right»]. Retrieved from: http://eapcspeaksrussian. eu.aspx. [in Ukrainian].
[2] YeAPD. (2011). Bila knyha standartiv z paliatyvnoi dopomohy. Rekomendatsii Yevropeiskoi Asotsiatsii paliatyvnoi dopomohy [White Paper on standards and norms for hospice and palliative care in Europe. Recommendation of the European Association of Palliative Care]. Retrieved from: http://ligalife.com.ua/2011/paliativna/standart/ 4parent-kontekstta-metodologiyal. [in Ukrainian].

[3] Internet-sajt MCYKZh. [Website MTSIKZH]. Retrieved from http://www. mcqli.da.ru. [in Russian].

[4] Velikaya, O. V., \& Akulova, A. V. (2015). Ocenka kachestva zhizni zhenshchin, bol'nykh tuberkulezom legkikh, s ispol'zovaniyem ankety SF-36 [Evaluation of the quality of life of women, patients with pulmonary tuberculosis, using the SF-36 questionnaire]. Nauchnye vedomosti, 16(213), 110-115. [in Russian].

[5] Aniskina, E. A., Makarova, I. I., Strakhov, K. A., \& Al-Daud, S. D. (2012) Issledovaniye kachestva zhizni bol'nykh tuberkulezom legkikh [Study of quality of life of patients with pulmonary tuberculosis]. M'edicinskaya ekologiya, 4, 58-62. [in Russian].

[6] Tsapenko, Y. P., Boiko, M. G., Kraevska, O. O., Alieva, N. M., \& Krasnoshapka, Y. O. (2012). Porivnialna kharakterystyka yakosti zhyttia ta stanu zdorov'ia khvorykh infiltratyvnym tuberkulozom lehen v dynamitsi na riznykh etapakh medychnoi reabilitatsii [Comparative characteristics of life quality and health condition in patients with infiltrative tuberculosis of lungs in dynamics during different stages of medical rehabilitation]. Svit biolohii ta medytsyny, 3, 112-115. [in Ukrainian].

[7] Ministry of Health of Ukraine (2014). Nakaz Ukrainy «Unifikovanyi klinichnyi protokol pervynnoi, vtorynnoi (spetsializovanoi) ta tretynnoi (vysokospetsializovanoi) medychnoi dopomohy doroslym. Tuberkuloz» vid 31.12.14 roku №620 [Order of Ukraine «Unified clinical protocols of primary, secondary (specialized) and tertiary (highly specialized) medical care for adults. Tuberculosis» from December 31, 2014 №620]. [in Ukrainian].

[8] WHO. (2015). Global Tuberculosis Report 2015. Retrieved from http:// apps.who.int/iris/bitstream/10665/191102/1/9789241565059 eng.pdf.

[9] Ware, J. E. (1992). The MOS 36-Item Short-Form Health Survey. Med. Care, 30, 473-483.

[10] Santos, A. P. C. Lazzari, T. K., \& Silva, D. R. (2017) .Health-Related Quality of Life, Depression and Anxiety in Hospitalized Patients with Tuberculosis. Tuberculosis and respiratory diseases, 80(1), 69-76. doi: 10.4046/trd.2017.80.1.69.

[11] Sagwa, E. L., Ruswa, N., Mavhunga, F., Rennie, T., Leufkens, H. G. M., \& Mantel-Tee,uwisse A. K. (2016). Adverse events and patients' perceived health-related quality of life at the end of multidrug-resistant tuberculosis treatment in Namibia. Patient preference and adherence, 10, 2369. doi: 10.2147/PPA.S116860.

[12] Fan, H. M., Wang, Z., Feng, F. M., Zhang, K. L., Yuan, J. X., Sui, H. et al. (2010). Association of TNF- $\alpha-238 \mathrm{G} / \mathrm{A}$ and $308 \mathrm{G} / \mathrm{A}$ Gene Polymorphisms with Pulmonary Tuberculosis among Patients with Coal Worker's Pneumoconiosis. Biomedical and Environmental Sciences, 23(2), 137-145. doi: 10.1016/S0895-3988(10)60043-8.

[13] Moges, B., Amare, B., Asfaw, F., Tesfaye, W., Tiruneh, M., Belyhun, Ye., et al. (2012). Prevalence of smear positive pulmonary tuberculosis among prisoners in North Gondar Zone Prison, northwest Ethiopia. BMC infectious diseases, 12, 352. doi: 10.1186/1471-2334-12-352. 